important were embodied in his books on "Men and their Motives" (1934) and "Man, Morals, and Society" (1945). He served for some time as honorary secretary of the International Psychoanalytic Association ; and in 1948 was elected chairman of the programme committee of the International Congress on Mental Health. Two years later he was appointed president of Section J (Psychology) of the British Association.

To the end of his life Flugel continued to give regular lectures at University College and to take an active part in the work of the British Psychological Society and its numerous committees. But his abiding work lies in his fruitful attempts to synthesize Freudian psychoanalysis with the orthodox tenets of British psychology as taught by Ward, Stout and McDougall.

CyrIl Burt

\section{Mr. Philip Lyle}

Philip LyLe, who died on July 15, was the elder son of the late John Lyle, of Weybridge, and grandson of Abram Lyle, the founder of the sugar-refining company which was later arnalgamated with Henry Tate and Sons to form Tate and Lyle, Ltd. He was born on November 26,1885 , and was educated at Rugby, in Switzerland and at University College, London. $\mathrm{He}$ later applied himself to statistical mathematics, which he put to very good use in the sugar industry.

As a director of Tate and Lyle, first at Plaistow refinery, Philip Lyle participated in raising the low thermal efficiency, poor scientific control and low output of the refinery until it held one of the foremost positions in the world. He paid special attention to losses incurred in sugar refining and consequently to methods of sugar analysis. In 1947 he was responsiblo for broadening the Company's outlook towards research and enlarging its research activities. As chairman of the Research and Development Committee he was invaluable in guidance and judgment.

Mr. Lyle's own scientific contributions were best known in refinery circles; but a few exceptions include "Heat of Solution of Sucrose", which explained discrepancies in heat balances in refineries. The "Sugar Industry" and "Constructions of Nomograms for use in Statistics" appeared in the Journal of the Royal Statistical Society and Applied Statistics, respectively. He was a notable member of both the Royal Statistical Society and its Industrial Applications Section, being one of the two secretaries and editors of the former and on the Editorial Committee of the latter. In 1944 he published "Regression Analysis of Production Costs and Factory Operations".

Philip Lyle was a director of the West Indies Sugar Co. of Jamaica, and Caroni, Ltd., of Trinidad. He made a special study of statistical treatment of agronomical problems. He was also a director of Colonial Yeast, Ltd., which had been founded by the Sugar Commission to produce cheap protein and vitamins (Thaysen's Torula utilis) needed in the Caribbean, from surplus cane molasses. The product could not find a market there or elsewhere, and the project was abandoned; but his faith in the necessity for protein production to supply under-nourished peoples was unfailing, and he read' a paper on the subject before the Nutrition Society in 1950.

The Sugar Reorganization Act, 1936, was responsible for formation of Research Committeng $A$ and $B$, of which he was a member. The programme for $B$ was largely that put forward by him and was adopted in part by the Colonial Research Committee. Other pro- posals were chemical research into by-product utilization and sucro-chemistry, which were implemented at the University of Birmingham under Sir Norman Haworth and later Prof. L. F. Wiggins. Physicochemical research at the University of Bristol was financed first by the Commission and later by Tate and Lyle and the British Sugar Corporation.

Among unpublished work which has nevertheless been widely adopted and utilized is his "Analysis of Sugar Grists", in which he showed that the normal frequency curves allowed grists to be expressed in terms of mean aperture and coefficient of variation.

So much for his interests and work. What of the man? To meet Philip Lyle was to like him. To know him was to admire, respect and love him. His encouraging manner, his friendly approach, his sunny smile (the same to people in all walks of life) made everyone his friend, and effort on his behalf a pleasure; Browning might have altered the lettering of "Pippa passes". He leaves a widow, a daughter, two sons, one of whom is following in his footsteps, several grandehildren and innumerable friends.

\section{H. C. S. DE WhatiLey}

\section{Sir Francis McClean}

Frank McClean was best known to the outside world as the great patron of aviation and the founder of amateur and naval flying in Great Britain. Born on February 1, 1876, and educated at Charterhouse, Clifton and Coopers Hill, he served with the Public Works Department in India during 1898-1902. After flying in two Gordon-Bennett balloon races in 1907-8, he flew with Wilbur Wright at Le Mans in the latter year. He bought land in the Isle of Sheppey for his early flying experiences on heavier-than-air machines and lent aircraft to the Admiralty so that naval officers could learn to fly. After some pioneering work in submarine photography, he caused some sensation by flying up the Thames in a seaplane, passing between the upper and lower parts of the Tower Bridge and under London Bridge. He joined the R.N.A.S. on the outbreak of the First World War, served on Channel patrol and then became chief instructor at Eastchurch. When the R.A.F. was formed he took a commission, but resigned in 1919 .

McClean's other great interest lay in astronomy ; in this he was influenced by his father, Dr. Frank MeClean. He organized two eclipse expeditions, to Flint Island in 1908 and to Port Davey in Tasmania in 1910. He also joined an expedition led by Sir Norman Lockyer to Vavau Island in 1911. He was a joint founder of the Norman Lockyer Observatory on Salcombe Hill, Sidmouth, serving under his friend, Sir Richard Gregory, on its council. The Frank MoClean Dome and the twin telescope and sidereal clock which it houses bear further witness to his generosity. His 21-in. siderostat, bought for his eclipse expeditions, was presented by him to the Cambridge Observatories. With his brothers, he was a generous benefactor also to the Coins and Manuscripts Departments of the Fitzwilliam Museum, Cambridge. Other social activities are reflected in his holding the office of High Sheriff of Oxfordshire in 1932 and the presidency of the Royal Aero Club for two spells. He was the senior member of the Royal Astronomical Society Club, and was much loved by a wide circle of friends in flying and astronomical circlew. He died on August 11 after a long illness, leaving a widow and two daughters.

F. J. M. Stratton 